\title{
CONCENTRATION OF TOBACCO MARKET: EVIDENCE FROM SERBIA
}

\author{
Bojana Vukovićl, Kristina Mijićn', Nataša Spahić ${ }^{3}$
}

\begin{abstract}
Summary
This paper presents a research on market concentration of tobacco producers in the Republic of Serbia during 2010-2013. Market concentration was measured by Herfindahl Hirschman index (HHI) and Concentration index (CRn) based on independent variables: operating revenue, net earnings, equity and number of employees. The research of market concentration of tobacco producers based on operating revenue as the most referential variable indicated that the market of tobacco producers in the Republic of Serbia was highly concentrated and that it was an oligopoly. Leading companies dominated in the terms of the value of realized net earnings, equity and number of employees. Although leading companies had dominance in market share of Serbia, they had worse operating results in terms of effectiveness, structure of assets and financial performance in observed period.
\end{abstract}

Key words: production of tobacco, market concentration, Serbia

JEL: $M 40, G 17, Q 10$

\section{Introduction}

Production of tobacco is a highly profitable branch of tobacco industry. Tobacco is mostly produced in Asia. China and United States are on the top of the world's tobacco production. In the international market tobacco production is represented by dominance of six companies: China National Tobacco Corporation, Japan Tobacco Inc., British American Tobacco, Philip Morris International, Altria Group Inc. and Imperial Tobacco Group. Market production and processing of tobacco in countries around the World is characterized by participation of these leading companies.

These six companies operate in domestic and international markets. Japan Tobacco Inc. covers about $70 \%$ of Japan's tobacco market. It owns 31 plantations at 23 locations. China National

1 Bojana Vuković, Ph.D, Teaching Assistant, Faculty of Economics Subotica, Segedinski put Street no. 9-11, 24000 Subotica, Serbia, Phone: +381 24628 000, E-mail: bojanavuk@ef.uns.ac.rs

2 Kristina Mijić, Ph.D, Teaching Assistant, Faculty of Economics Subotica, Segedinski put Street no. 9-11, 24000 Subotica, Serbia, Phone: +381 24628 000, E-mail: mijick@ef.uns.ac.rs

3 Nataša Spahić, Ph.D, Assistant Professor, Faculty of Sciences, Trg Dositeja Obradovića Street no. 3, 21000 Novi Sad, Serbia, Phone: +381 2148528 64, E-mail: natasa.spahic@dmi.uns.ac.rs

EP 2015 (62) 2 (385-398) 
Tobacco Corporation, as a state-owned tobacco company produces and owns a portfolio of over 900 brands in the world's market. British American Tobacco is supplying 180 regional markets with over 200 products through its affiliated companies. Similarly, Philips Morris International through related companies operates in the European Union, Eastern Europe, Middle East, Africa, Asia, South America and Canada. Altria Group Inc., as one of the largest tobacco companies in the market, in its composition to 2008 has Philip Morris International. Imperial Tobacco Group operates in 160 countries through a large number of production departments. The business activities of the company are divided on tobacco and logistics.

Depending on the market share of leading and other companies in tobacco industry, the market can range from perfect competition to oligopoly. Higher concentration in the market of tobacco industry determines the behaviour of these large companies. In such circumstances, other companies have a problem with increasing competition, especially because market for tobacco products is particularly depended on changing prices.

The concentration on the different markets can be measured using several statistical and econometric methods, such as the Herfindahl-Hirschman index (HHI), Concentration ratios (CRn), Gini coefficient, Linda index, Hannah-Kay index, Hall Tideman index etc. For example, Brezina and associates (2012) estimated a concentration of banking services in Slovakia by HHI and CRn. Marinkovic (2012) measured the concentration of the market for banking services in Serbia by HHI index. Mijic and associates (2014) investigated the concentration of the market for audit services in the Republic of Serbia by HHI and CRn. Njegomir and Stojic (2010) considered a non-life insurance market concentration in former Yugoslavia by using $\mathrm{HHI}$ index.

Based on guidelines by the Organisation for Economic Co-operation and Development, the most relevant and the most common indices for measuring market concentration are $\mathrm{HHI}$ and CRn. Based on these indices and Gini coefficient, Kanyenga and Mangisoni (2006) analysed the concentration of the market for tobacco products in the Republic of Malawi for 19962006. U.S. Department of Justice and Federal Trade Commission in 1998 investigated the concentration of market for tobacco products in the United States by HHI. The conclusions were that the market was highly concentrated. The major position had a company Philip Morris Inc. with a market share of $47.80 \%$. Chenqing and associates (2013) measured the market structure of tobacco industry of China for 2001-2011 by HHI index and CRn. The results showed that tobacco industry in China was in a high moderate oligopolistic market structure. Similarly, Kahyarara (2011) researched the level of concentration of the tobacco market in Tanzania. The results showed that the market was highly concentrated and that top three or top four firms produced more than 50 percent of total production in 2001-2007. The author also pointed out fluctuations in the level of concentration during the observed period. Mariniello and Antonielli (2014) measured in their study, concentration of manufacturing sectors from five major European economies (France, Germany, Italy, Spain and the United Kingdom) between 2000 and 2011 by HHI and CRn. The results showed that tobacco was one of the most concentrated sectors with the top four firms in production. Mirza (2014) estimated market concentration in manufacturing, financial and service sectors of Pakistan for 2011 and compared these results with previous years. HHI index and CR3 ratio had been 
used to compute market concentration for every branch of industry, among which tobacco industry was.

Tobacco industry in Serbia is segmented into production of tobacco, processing tobacco and production of tobacco products. In accordance with privatization processes, there are four companies in production of tobacco products in the Republic of Serbia: Phillips Morris Operations AD Nis, British American Tobacco AD Vranje, Monus doo Belgrade, JT International AD Senta (Ministry of finance, 2014).

In the field of production of tobacco are presented companies Phillips Morris Operations AD Nis, Monus doo Belgrade, JT International AD Senta, but also the companies of domestic market (Ministry of finance, 2014). On this basis, the subject of research in following part of paper is the level of market share and position of leading and other companies of domestic market.

The study of market concentration for tobacco producers were conducted by HHI index and variables: operating revenue, net earnings, equity and number of employees. The research was conducted on the basis of financial statements of companies in the field of tobacco production in 2010-2013. Financial statements were publicly disclosed on the site of Serbian Business Registers Agency.

\section{Methods for measurement of market concentration}

Different statistical and econometric methods can be used for the measurement of market concentration. OECD (1993) recommends two methods: Herfindahl-Hirschman index (HHI) and the Concentration ratios (CRn).

Herfindahl-Hirschman Index (HHI) is a measure of the size of companies in relation to the industry and an indicator of the amount of competition among them. HHI is a convex function of the market share of companies in the sector (industry). It is defined as the sum of the squares of the market shares of all companies in the industry (U.S. Department of Justice and the Federal Trade Commission, 2010).

$$
\mathrm{HHI}=\sum_{i=1}^{n} S_{i}^{2}
$$

Where:

$\mathrm{S}_{\mathrm{i}-\mathrm{t}}$ the market share of the company in the market, $\mathrm{n}$ - the number of companies.

HHI ranges from 1/N to one (Djolov, 2013). The maximum value of the HHI index of one indicates that the market is highly concentrated (monopolistic) and that entire market is supplied by one company. On the other hand, the minimum value of $1 / \mathrm{N}$ indicates that companies have equal market shares and the market is perfectly competitive. The level of market concentration measured by the HHI index could be explained by different scales. 
U.S. Department of Justice and the Federal Trade Commission in the U.S. (2010) have defined the following scale of HHI index:

1. HHI index is below 0.01 , the market is highly competitive,

2. HHI index is below 0.15 , the market is not concentrated,

3. HHI index is between 0.15 to 0.25 , the market is moderately concentrated,

4. HHI index is above 0.25 , the market is highly concentrated.

According to another classification, provided by European Commission (2004), HHI index could be explained by different scale:

1. not concentrated markets: $\mathrm{HHI}$ is below 0.10 ,

2. moderately concentrated markets: $\mathrm{HHI}$ is between 0.10 to 0.20 ,

3. highly concentrated markets: HHI is above 0.20 .

Concentration ratio $(\mathrm{CRn})$ is the percentage of market share held by the largest companies in an industry (European Commission, 2004).

$\mathrm{CR}_{\mathrm{n}}=\sum_{i=1}^{n} S_{i}$

Where:

$\mathrm{n}$ - the number of leading companies,

$\mathrm{S}_{\mathrm{i}}$ - the market share.

Concentration index indicates whether the industry is dominated by a few large companies or a number of smaller companies. Indices for measuring industrial concentration are commonly used for four or eight top companies. If the value of the index of industrial concentration is $100 \%$, it is assumed that there is a pure monopoly or monopolistic position in terms of market share of observed companies. The value of the index of industrial concentration can be even greater if a small number of companies control the market. The market is categorized as oligopolistic and highly concentrated when the index value is greater than or equal to $75 \%$.

Focusing only on four or eight, not three or six leading companies in the market, has an arbitrary character and can provide very limited information on actual market structure. Since the objective of this paper was to examine the market concentration for tobacco producers in Serbia, by the index of industrial concentration, we considered share of three leading companies in Serbian market of tobacco producers.

\section{Characteristics of market for tobacco products in Serbia}

In the Republic of Serbia, tobacco industry has been determined as production of tobacco, processing of tobacco and manufacturing of tobacco products (Ministry of finance, 2014). Manufacturing of tobacco products is categorized as processing of tobacco in order to obtain 
final product. In accordance with the classification of activities of Institute of Statistics, manufacturing of tobacco products has been determined as:

1. Production of tobacco products and the replacement for tobacco: cigarettes, tobacco cigarette, cigar,

2. Pipe tobacco, chewing tobacco, snuff, etc.,

3. Production of homogenized or reconstituted tobacco (SORS, 2014).

The market for tobacco products in Serbia in the process of privatization had been characterized by certain changes. Tobacco Industry Nis was privatized by Philip Morris. Philip Morris took over the tobacco industry Nis, while British American Tobacco took over the tobacco industry Vranje. Strategic Partnership Tobacco Industry Nis and Philip Morris Holland BV worth 518 million EUR were most successful privatization in tobacco industry in Eastern Europe. In the privatization, Japan Tobacco International purchased tobacco industry Senta for 253 EUR per shares, which at that time was six times higher than its carrying values (Market Network, 2014).

\section{Analysis of the results of market concentration in production of tobacco products in Serbia}

The degree of concentration and the level of market share determine the nature of the market and competition, which can range from perfect competition to oligopoly. Low concentrations indicate perfect competition, i.e a market that is relatively equally divided between market participants. When the market is dominated by a small number of companies, the assumption is that the market is concentrated and oligopolistic. Nowadays, the market for production and processing of tobacco is highly oligopolistic and highly concentrated, which implies high barriers to entry and better market positioning of smaller companies in the market.

Market concentration of tobacco producers in Serbia was measured by HHI index and CRn index in 2010-2013. Analysis of the level of market concentration was based on the value of determined indicator by European Commission. Variable operating revenue was primarily used for measuring market concentration. In addition, we used variables: net earnings, equity and number of employees in order to analyse characteristics of the market for tobacco products.

The objective of the analysis is to answer the following questions:

1. If concentration is measured on the basis of value of operating revenue, can we conclude that the market for tobacco producers in the Republic of Serbia is oligopolistic?

2. Are there differences in conclusions about dominance in market when different independent variables are applied (net earnings, equity, number of employees)?

3. Does the dominance according to market share imply higher profitability? 
The values of independent variables for measuring concentration are presented in the Table 1. The values of independent variables (operating revenue, net earnings, equity and number of employees) are presented for leading and other companies in this industry.

Table 1. Operating revenue, net earnings, equity and number of employees for leading companies and other companies in production of tobacco in Serbia (period of 2010-2013)

\begin{tabular}{|l|r|r|r|r|r|}
\hline \multirow{2}{*}{\multicolumn{5}{|c|}{ Independent Variables }} & \multicolumn{5}{c|}{ Year } \\
\cline { 2 - 5 } & \multicolumn{1}{|c|}{$\mathbf{2 0 1 0}$} & $\mathbf{2 0 1 1}$ & \multicolumn{1}{|c|}{$\mathbf{2 0 1 2}$} & \multicolumn{1}{|c|}{$\mathbf{2 0 1 3}$} \\
\hline Operating Revenue & 23.833 .290 & 22.877 .181 & 28.531 .479 & 33.662 .813 \\
\hline Leading Companies & 1.231 .577 & 1.223 .836 & 1.733 .194 & 1.696 .298 \\
\hline Other Companies & 25.064 .867 & 24.101 .017 & 30.264 .673 & 35.359 .111 \\
\hline Total & 1.447 .729 & 381.050 & -757.205 & 2.756 .239 \\
\hline Net Earnings & 73.581 & 88.278 & 165.477 & 173.166 \\
\hline Leading Companies & 1.521 .310 & 469.328 & -591.728 & 2.929 .405 \\
\hline Other Companies & 17.541 .272 & 16.210 .535 & 18.208 .022 & 19.470 .630 \\
\hline Total & 540.103 & 616.839 & 923.265 & 975.092 \\
\hline Equity & 18.081 .375 & 16.827 .374 & 19.131 .287 & 20.445 .722 \\
\hline Leading Companies & \multicolumn{5}{|c|}{} \\
\hline Other Companies & 965 & 869 & 902 & 912 \\
\hline Total & 170 & 152 & 157 & 150 \\
\hline Number of Employees & 1.135 & 1.021 & 1.059 & 1.062 \\
\hline Leading Companies &
\end{tabular}

Source: Authors' calculation according to data from financial statements, Serbian Business Registers Agency (SBRA), http://www.apr.gov.rs

Note: Values are in thousands of RSD (except for number of employees)

The results of concentration in the market for tobacco producers in Serbia are presented in Table 2:

Table 2. Concentration in the market for tobacco producers in the Republic of Serbia

\begin{tabular}{|c|c|c|c|c|}
\hline \multirow{2}{*}{$\begin{array}{c}\text { Market } \\
\text { Concentration } \\
\text { Indices }\end{array}$} & \multicolumn{4}{|c|}{ Independent variables } \\
\hline & \begin{tabular}{|l|} 
Operating \\
Revenue
\end{tabular} & Net Earnings & Equity & $\begin{array}{l}\text { Number of } \\
\text { Employees }\end{array}$ \\
\hline HHI 2010 & 0,50 & - & 0,50 & 0,50 \\
\hline HHI 2011 & 0,47 & - & 0,51 & 0,32 \\
\hline HHI 2012 & 0,45 & - & 0,56 & 0,27 \\
\hline HHI 2013 & 0,50 & 0,57 & 0,48 & 0,27 \\
\hline CR3 2010 & $95 \%$ & $95 \%$ & $97 \%$ & $85 \%$ \\
\hline CR3 2011 & $95 \%$ & $81 \%$ & $96 \%$ & $85 \%$ \\
\hline CR3 2012 & $94 \%$ & $88 \%$ & $95 \%$ & $85 \%$ \\
\hline CR3 2013 & $96 \%$ & $94 \%$ & $95 \%$ & $86 \%$ \\
\hline
\end{tabular}

Source: Authors' calculation according to data from financial statements, Serbian Business Registers Agency (SBRA), http://www.apr.gov.rs 
The results of measurement by HHI index and CR3 indicated that the market for tobacco producers in Republic of Serbia was highly concentrated and ranged from oligopoly to monopoly during 2010-2013. We concluded that the leading companies occupied 95\% of the market for tobacco producers in the Republic of Serbia.

Analysing the market concentration for tobacco producers according to the value of net earnings, we confirmed previously conclusion about oligopolistic market and high industrial concentration. One of the leading companies was operating at a loss in 20102012, so the analysis of industrial concentration markets by HHI index did not make a sense in this period.

Operating loss of one of the leading companies may be result of transfer pricing, that are all selling different brands as a subsidiary of parent company abroad (Milačić et al., 2013). Results of measurement, based on value of equity in this period, also indicated a high concentration of the market. Leading companies had the highest value of equity in this branch of tobacco industry. There was a slight decrease in dynamics, which changed the market position of leading companies. From the point of value of total equity, market almost had monopoly characteristics in 2010. The growing interest of the market leaders and visibly weak competition lead to greater opportunities for monopolistic behavior and freedom in forming prices.

From the point of number of employees in companies of tobacco producers in Serbia, we also concluded that it was an oligopolistic market or market with a dominance of leading companies. HHI index was higher than 0.25 during observed period. Fluctuations in the value of concentration index and HHI index were the result of reducing the number of employees. The purpose for reduction was keeping competitiveness and sustainability of the business of leading companies in the Republic of Serbia. 
Figure 1. CR4 index according to operating revenue, net earnings, equity and number of employees in 2010-2013.

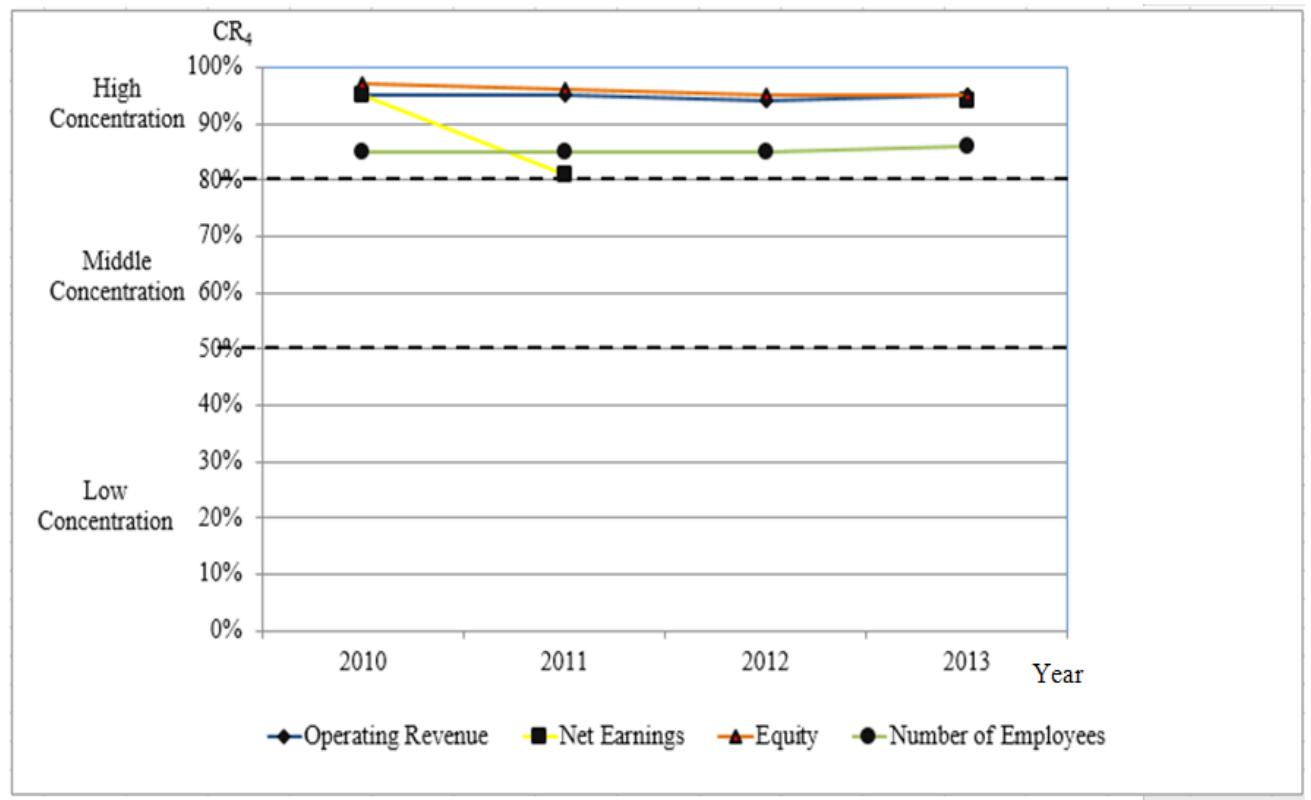

Source: Authors' calculation according to data from financial statements, Serbian Business Registers Agency (SBRA), http://www.apr.gov.rs

Based on obtained results, we concluded that leading companies dominated in production of tobacco at Serbian market. There was a high degree of industrial concentration with elements of oligopoly. Does the dominance in terms of market share imply better performance of leading companies? We would try to answer this question in further consideration.

\section{Analysis of business performance of companies in production of tobacco in the Republic of Serbia}

In this part of paper, we researched whether the leading companies in production of tobacco in the Republic of Serbia would dominate in terms of earnings, structure of assets and financial performance. The research was based on financial reports of companies in production of tobacco in order to evaluate performance. The performance was evaluated on the basis of selected indicators of success, assets structure and financial performance (Palepu et al., 2012). There were displayed average values for these indicators of leading and other companies in production of tobacco.

By measuring performance and success of companies in production of tobacco, we obtained following results. 
Table 3. Earnings ability of companies in production of tobacco in the Republic of Serbia

\begin{tabular}{|l|r|r|r|}
\hline \multicolumn{2}{|c|}{ Indicators of Earnings Ability } & \multicolumn{3}{c|}{ Year } \\
\cline { 2 - 4 } & $\mathbf{2 0 1 1}$ & $\mathbf{2 0 1 2}$ & $\mathbf{2 0 1 3}$ \\
\hline Return on Equity (Operating Earnings/Average Equity) & $5 \%$ & $5 \%$ & $5 \%$ \\
\hline Leading Companies & $9 \%$ & $9 \%$ & $6 \%$ \\
\hline Other Companies & $11,21 \%$ & $69,76 \%$ & $40,24 \%$ \\
\hline Return on Shareholders' Equity (Net Earnings/Average Shareholder Equity) \\
\hline Leading Companies & $3.272,82 \%$ & $8.019,85 \%$ & $5.988,74 \%$ \\
\hline Other Companies &
\end{tabular}

Source: Authors' calculation according to data from financial statements, Serbian Business Registers Agency (SBRA), http://www.apr.gov.rs

According to the results, we concluded that there was negative correlation between market share and profitability of leading companies. So, the dominance in terms of market share did not imply a higher return on asset. So, the leading companies did not have the primacy in terms of value of return on invested assets. The rate of return of leading companies was less than rate of return of other companies in production of tobacco during observed period. The rate of return on asset of leading companies did not show significant fluctuations in dynamics. It was constant at 5\%. Furthermore, the rate of return on asset of other companies was declined from $9 \%$ to $6 \%$ in 2013 , which suggested that it reduced ability of other companies for achieving higher value of return on asset in production of tobacco.

The value of return on shareholder's equity also indicated that leading companies did not realize the primacy of the market of tobacco producers. The rate of return on shareholder's equity of leading companies was less than the rate of return on shareholder's equity of other companies in production of tobacco. We saw the same fluctuations of value in dynamics in both groups, i.e. an increase in rate on shareholder's return from 2011 to 2012, and then decline in 2013.

Analysis of structure of assets of company in producing tobacco in Serbia was carried out according to the value of turnover of current assets and assessment of the effectiveness of total assets of company. The rate of current assets measured on the basis of coefficient and number of days of single rate. Analysis the efficiency of assets was derived from the time necessary to repay invested funds in assets. The results were shown in Table 4.

Table 4. Indicators of assets structure of the company in tobacco production in the Republic of Serbia

\begin{tabular}{|l|r|r|r|}
\hline \multirow{2}{*}{ Indicators of Assets Structure } & \multicolumn{3}{|c|}{ Year } \\
\cline { 2 - 4 } & \multicolumn{1}{|c|}{$\mathbf{2 0 1 1}$} & $\mathbf{2 0 1 2}$ & $\mathbf{2 0 1 3}$ \\
\hline Indicator of Turnover of Current Assets (Operating Revenue/Average Current Assets) \\
\hline Leading Companies & 0,83 & 1,18 & 1,26 \\
\hline Other Companies & 0,50 & 1,97 & 251,31 \\
\hline Number of Days of Turnover of Current Assets (365/Turnover of current assets) \\
\hline Leading Companies & 440 & 309 & 289 \\
\hline Other Companies & 731 & 185 & 1 \\
\hline Payoff of assets (Average Assets/Net Earnings+ Depreciation and Provisions) \\
\hline
\end{tabular}

EP 2015 (62) 2 (385-398) 


\begin{tabular}{|l|r|r|r|}
\hline \multirow{2}{*}{\multicolumn{1}{|c|}{ Indicators of Assets Structure }} & \multicolumn{3}{|c|}{ Year } \\
\cline { 2 - 4 } & $\mathbf{2 0 1 1}$ & $\mathbf{2 0 1 2}$ & \multicolumn{1}{|c|}{$\mathbf{2 0 1 3}$} \\
\hline Leading Companies & 108 & 89 & 154 \\
\hline Other Companies & 21 & 35 & 33 \\
\hline
\end{tabular}

Source: Authors' calculation according to data from financial statements, Serbian Business Registers Agency (SBRA), http://www.apr.gov.rs

According to the results, we concluded that leading companies had more effective turnover of current assets in 2011. It was necessary 291 days less for turnover of current assets. In remaining period, leading companies noted substantially lower efficiency of turnover of current assets. Other companies had a significant dominance in terms of turnover of current assets in 2013. This fact created preconditions for achieving higher value of operating revenues. On the other hand, higher efficiency of current assets created preconditions for lower costs of holding inventory and financing current assets. This fact also made a possibility of higher financial results of other companies.

Other companies in production of tobacco also noted better results in terms of number of years necessary for returning assets in cash. Leading companies had a higher payoff of assets, which had indicated a lower efficiency of total assets. It was noticeable the opposite tendencies in the values of indicators of studied groups. The highest efficiency of total assets of leading companies recorded in 2012. On the other hand, other companies achieved the lowest efficiency of total assets in 2012.

Analysis of financial performance of companies in production of tobacco in Serbia was conducted based on assessment of repaying debts, the level of funding from external sources and financing the liability with available assets. On this basis, we used the indicators of liquidity, indebtedness and solvency. The results of measurements were presented in Table 5.

Table 5. Indicators of financial performance of companies in production of tobacco in Republic of Serbia

\begin{tabular}{|l|r|r|r|r|}
\hline \multirow{2}{*}{ Indicators of Financial Performance } & \multicolumn{5}{c|}{ Year } \\
\cline { 2 - 5 } & $\mathbf{2 0 1 0}$ & $\mathbf{2 0 1 1}$ & $\mathbf{2 0 1 2}$ & $\mathbf{2 0 1 3}$ \\
\hline $\begin{array}{l}\text { Current Liquidity (Current Assets/Short-Term Liabilities) } \\
\text { Reference Value }>2\end{array}$ & 1,21 & 1,22 & 1,49 & 1,25 \\
\hline Leading Companies & 1,19 & 1,03 & 1,57 & 2,46 \\
\hline Other Companies & 1,83 & 2,47 & 1,34 & 1,46 \\
\hline Indebtedness (Liability/ Equity) & 0,87 & 1,33 & 1,26 & 1,10 \\
\hline Leading Companies & \multicolumn{5}{|c|}{} \\
\hline Other Companies & 1,77 & 1,77 & 2,37 & 1,91 \\
\hline $\begin{array}{l}\text { Solvency (Assets/Liability) } \\
\text { Reference Value }>1\end{array}$ & 1,24 & 0.96 & 1,71 & 3,03 \\
\hline Leading Companies &
\end{tabular}

Source: Authors' calculation according to data from financial statements, Serbian Business Registers Agency (SBRA), http://www.apr.gov.rs 
According to the value of analysis of current liquidity ratio, we concluded that leading companies did not achieve to repay short-term obligations with available current assets during observed period. Only other companies in tobacco production were able to achieve current liquidity in 2013. Leading companies noted better results at the beginning of the observed period, i.e. in 2010 and 2011. After that, the primacy in terms of ability to repay short-term liabilities had other companies in production of tobacco.

Leading companies had a higher level of indebtedness during observed period. So, the measurement was following: 1 RSD equity for 1.83 RSD debt in 2010, 2.47 RSD debt in 2011, 1.34 RSD debt in 2012 and 1.46 RSD debt in 2013. On the other hand, 1 RSD equity of other companies for $0.87,1.33,1.26$ and $1.10 \mathrm{RSD}$ debt respectively. There was positive trend, because the level of indebtedness of other companies in tobacco production was reduced in 2011-2013.

According to the ratio of solvency of companies, we concluded that leading companies were able to repay debts with available assets during observed period. Solvency of leading companies was significantly better compared to solvency of other companies. Other companies in tobacco production noted a higher level of ability to repay debts at any period of time, even in the case of liquidation or bankruptcy.

\section{Conclusion}

Market concentration of tobacco producers in Serbia was measured based on HHI and CRn index. The result was that the market was oligopolistic. So, in the Republic of Serbia, as in most countries around the world, leading companies had a dominant market share, based on the value of operating revenue. The value of HHI index measured by the value of operating revenue was consistently above 0.20 in observed period. In addition, the value of concentration index indicated that almost two thirds, or $95 \%$ of annual value of operating revenue of the entire production of tobacco belonging to leading companies. Participation of other companies in this market was almost unnoticed.

Analysing market concentration according to the value of net earnings, equity and number of employees, we concluded that leading companies had a dominant position in distribution of net earnings, available equity and number of employees. It was obvious that the loss in business of leading companies had an impact on loss of entire sector. Present fluctuations in terms of number of employees were the result of efforts to be a competitive and sustain operations for leading companies in the Republic of Serbia.

In the last part of analysis of performance of business companies in production of tobacco, we examined whether dominance in terms of market share would result in better performance. The study results pointed lower success of leading companies. Leading companies had a dominant market share, but they realized lower return on engaged resources and institutional investments.

Analysis of assets structure pointed to weaker efficiency of turnover of current assets and longer time required that the funds invested in total assets return in form of cash. On this basis, 
conclusions were that the financial performances of other companies in producing tobacco were significantly better compared to the financial performance of leading companies. In addition, leading companies had a higher level of indebtedness, based on equity and debts ratio in reporting period. Leading companies had primacy only in terms of ability to repay the total debts from the assets on longer time prospects.

Summarizing obtained results of research, we concluded that there was a negative correlation between market share and performance indicators of leading companies in the field of tobacco production in the Republic of Serbia. So, leading companies had a dominant position in market of Serbia, but also weaker operating results in terms of effectiveness, assets structure and financial performance in observed period. It was evident that leading companies motivated by profit as the ultimate goal of business, decided to take advantage of domestic market in terms of cheaper inputs and lower tax in production of tobacco. In addition, the price for tobacco in the domestic market was considerably higher compared to other countries in the region. Leading companies were motivated to place tobacco in many factories around the world, where the price for tobacco products was several times higher.

\section{Literature}

1. Brezina, I., Pekar, J., Čičkova, Z. (2012): The Analysis of Concentration of Slovak Banking Sector, Proceedings of the Conference Strategic Management - Strategic Management and Overcoming the Economic and Financial Crisis, Subotica, Serbia, pp. 1-8.

2. Chenqing, S., Jialong, X., Xiaqxuan, Y. (2013): On the Study of Structure Optimization of Tobacco Industry in China, Proceedings of International Conference on Industrial Engineering and Management Science, DEStech Publications, Shanghai, China, pp. 667-674, available at: http://books.google.rs/books?id=ZTnFAQAAQBAJ\&pg=PA66 7\&lpg $=$ PA667\&dq $=$ On + the + Study + of + Structure + Optimization + of + Tobacco + Indust ry + in + China\&source=bl\&ots $=$ qw4PEIJ3cL\&sig=aGv4JYK 8TGT0NEranuvfCvAt AA\&hl $=$ sr\&sa $=$ X\&ei $=$ oUBNVKTTLKXnygOzo4DoBA\&ved $=0$ CCUQ6AEwAA\#v =onepage $\& q=O n \% 20$ the $\% 20$ Study $\% 20$ of $\% 20$ Structure $\% 20$ Optimization $\% 20$ of $\% 20$ Tobacco $\% 20$ Industry $\% 20 \mathrm{in} \% 20$ China\&f=false

3. Djolov, G. (2013): The Herfindahl-Hirschman Index as a Decision Guide to Business Concentration: A Statistical Exploration, Journal of Economic \& Social Measurement, pp. 201-227, Amsterdam, Netherlands, available at: http://iospress.metapress.com/ content/d753vm64lw242686

4. European Commission. (2004): Guidelines on the Assessment of Horizontal Mergers, Official Journal of European Union, pp. 5-18, Brussels, Belgium, available at: http://eurlex.europa.eu/legal-content/EN/TXT/PDF/?uri=CELEX:52004XC0205\%2802\%29\&f $\underline{\text { rom }=\mathrm{EN}}$

5. Kahyarara, G. (2011): Market Competition and Performance of Tanzanian Manufacturing, Proceedings of CSAE 25 th Anniversary Conference 2011 - Economic Development in Africa CSAE, Oxford, United Kingdom, pp. 1-24, available at: www. 
csae.ox.ac.uk/conferences/2011-edia/papers/488-Kahyarara.pdf

6. Kanyenga, M., Mangisoni, J. H. (2006): Assessing Market Concentration in the Tobacco Industry of Malawi, University of Malawi, Lilongwe, Malawi, available at: http://community.eldis.org/.59ee $3 \mathrm{fb} 9 /$ Assessing $\% 20$ market $\% 20$ concentration $\% 20$ in $\% 20$ the $\% 20$ tobacco $\% 20$ industry $\% 20$ of $\% 20$ malawi.pdf

7. Mariniello, M., Antonielli, M. (2014): Antitrust Risk in EU Manufacturing: A SectorLevel Ranking, Bruegel Working Paper 7/2014, European Commission, Brussels, Belgium, available at: www.bruegel.org/publications/publication-detail/publication/836antitrust-risk-in-eu-manufacturing-a-sector-level-ranking/

8. Marinković, M. (2012): Nivo koncentracije u bankarskom sektoru Srbije, Makroekonomske analize i trendovi, no. 217, pp. 39-41, Ekonomski institut, Beograd, Srbija.

9. Market Network (2014): Tržište cigareta u Srbiji, Bnetwork, Belgrade, Serbia, retrieved at: 15.08.2014, available at: http://marketnetwork.rs/retail/analiza/2064-trziste-cigareta$\underline{\mathrm{u}-\mathrm{Srbiji}}$

10. Mijić, K., Vuković, B., Jakšić, D. (2014): Koncentracija tržišta revizijskih usluga u Republici Srbiji, Ekonomske teme, vol. 52, no. 1, pp.117-130, Ekonomski fakultet, Niš, Srbija.

11. Milačić, S., Đukić, T., Pavlović, M. (2013): Analiza tokova gotovine preduzeća duvanske industrije u Republici Srbiji, Ekonomski pogledi, no. 3, pp. 1-20, Ekonomski fakultet, Kosovska Mitrovica, Srbija.

12. Ministry of Finance (2014): Arhiva-Analize i izveštaji, MoF, Belgrade, Serbia, retrieved at: 10.08.2014, available at: http://duvan.gov.rs/arhiva/analize

13. Mirza, A. B. (2014): Market Concentration in Manufacturing, Financial and Service Sectors in Pakistan, Pakistan Business Review, vol. 5, no. 4, pp. 563-578, Institute of Business Management, Karachi, Pakistan, available at: www.iobm.edu.pk/PBR/ PBR_1401_V15N4/PBR_V15N4.pdf

14. Njegomir, V., Stojic, D. (2010): Determinants of Insurance Market Attractiveness for Foreign Investments: The Case of Ex-Yugoslavia, Economic Research, no. 23, pp. 99110, Faculty of Economics, Pula, Croatia.

15. Organisation for Economic Co-operation and Development (OECD), (1993): Glossary of Industrial Organization Economics and Competition Law, OECD, Brussels, Belgium, available at: $\underline{\text { www.oecd.org/regreform/sectors/2376087.pdf }}$

16.Palepu, K., Healy, P., Bernard, V. (2012): Business Analysis \& Valuation-Using Financial Statements, Cengage Learning, London, United Kingdom.

17. Serbian Business Registers Agency (SBRA), (2014): Registar finansijskih izveštaja, Belgrade, Serbia, retrieved at: 11.08.2014, available at: www.apr.gov.rs

18. Statistical Office of Republic of Serbia (SORS), (2014): Klasifikacija, Belgrade, Serbia, retrieved at: 10.08.2014, available at: webrzs.stat.gov.rs/WebSite/userFiles/file/.../ Klasifikacija.pdf 
19.U.S Department of Justice and the Federal Trade Commission (1998): Multinationalmonitor, Department of Justice and the Federal Trade Commission, Washington, United States, available at: www.multinationalmonitor.org/ $\underline{\text { mm1998/111998/taub.html }}$

20.U.S. Department of Justice and the Federal Trade Commission (2010): Horizontal Merger Guidelines, United States: Department of Justice and the Federal Trade Commission, Washington, US.

\title{
KONCENTRACIJA TRŽIŠTA PROIZVOĐAČA DUVANA U REPUBLICI SRBIJI
}

\author{
Bojana Vukovič ${ }^{4}$ Kristina Mijič́n, Nataša Spahićc
}

\begin{abstract}
Rezime
U radu je sprovedeno istraživanje $i$ analiza koncentracije na tržištu proizvođača duvana u Republici Srbiji u vremenskom periodu 2010-2013. godina. Koncentracija na tržištu proizvodnje duvana merena je Herfindahl Hirschman indeksom (HHI) i Indeksom koncentracije (CRn) na bazi nezavisnih varijabli: poslovni prihod, neto rezultat, kapital $i$ broj zaposlenih. Rezultati istraživanja koncentracije tržišta proizvođača duvana pokazali su da je tržište u Republici Srbiji visoko koncentrisano i da ima karakteristike oligopola. Analizirajući koncentraciju tržišta prema visini neto rezultata, ukupnog kapitala i broja zaposlenih izveo se zaključak da "vodeće kompanije" zauzimaju dominantno mesto u raspodeli neto rezultata, raspolaganju kapitalom i zapošljavanju kadrova. Primetno je da ostvareni gubitak u poslovanju vodećih kompanija utiče na gubitak kompletnog sektora. Međutim, dominantno tržišno učešće vodećih kompanija ne implicira bolje performanse poslovanja. Bez obzira što su dominantne na tržištu Srbije, ,vodeće kompanije” beleže slabije rezultate poslovanja sa aspekta uspešnosti, imovinske strukture i finansijskih sposobnosti u posmatranom periodu. Dakle, dobijeni rezultati istraživanja ukazali su na negativnu korelaciju sa aspekta visine tržišnog učešća i ostvarenih pokazatelja poslovanja „vodećih kompanija” proizvodnje duvana, što nameće pitanja motiva poslovanja ,vodećih kompanija" na tržištu Republike Srbije.
\end{abstract}

Ključne reči: proizvođači duvana, koncentracija tržišta, Srbija

4 Dr Bojana Vuković, doktor ekonomskih nauka, asistent, Ekonomski fakultet, Segedinski put 9-11, 24000 Subotica, Srbija, Telefon: +381 24628 000, E-mail: bojanavuk@ef.uns.ac.rs

5 Dr Kristina Mijić, doktor ekonomskih nauka, asistent, Ekonomski fakultet, Segedinski put 9-11, 24000 Subotica, Srbija, Telefon: +381 24628 000, E-mail: mijick@ef.uns.ac.rs

6 Doc. dr Nataša Spahić, doktor ekonomskih nauka, Prirodno-matematički fakultet, Trg Dositeja Obradovića 3, 21000 Novi Sad, Srbija, Telefon: +381 2148528 64, E-mail: natasa.spahic@dmi.uns.ac.rs 